\title{
Metformin Reduces Post-Prandial Insulin Needs in Type I (Insulin-Dependent) Diabetic Patients: Assessment by the Artificial Pancreas
}

\author{
H.Gin ${ }^{1}$, G. Slama ${ }^{1}$, P. Weissbrodt ${ }^{1}$, T. Poynard ${ }^{2}$, P. Vexiau ${ }^{1}$, J.C. Klein ${ }^{1}$, and G. Tchobroutsky ${ }^{1}$ \\ ${ }^{1}$ Départment of Diabetes and INSERM, Hôtel-Dieu Hospital, Paris and \\ ${ }^{2}$ Départment de Statistiques Médicales and Unité de Recherches Statistiques, Institut Gustave Roussy, Villejuif, France
}

\begin{abstract}
Summary. It has been suggested that biguanides should be used in Type 1 (insulin-dependent) diabetic patients in order to diminish insulin requirements and reduce the chances of insulin reactions. The efficacy of these compounds in such patients has been controversial. We have studied the effect of metfor$\min (850 \mathrm{mg})$ given at $08.00 \mathrm{~h}$ in diminishing insulin needs after a 60 g carbohydrate mixed meal taken at $12.00 \mathrm{~h}$, using an artificial pancreas and a sequential analysis of the results. The morning test dose of metformin or placebo was preceded by $48 \mathrm{~h}$
\end{abstract}

treatment with metformin ( $850 \mathrm{mg}$ twice daily) or placebo. After the eighth patient a $26 \%$ saving of insulin need was demonstrated in the metformin-treated group $(p<0.01)$. Metformin is thus effective in reducing post-prandial insulin needs in Type 1 diabetic patients, although its use in such circumstances requires consideration of several other issues.

Key words: Type 1 diabetes, insulin, artificial pancreas, metfor$\min$.
The hypoglycaemic effect of biguanides in Type 2 (noninsulin-dependent) diabetes has been largely proved [1, 2]. Some authors have also tested these drugs in Type 1 (insulin-dependent) diabetic patients in attempts to reduce the daily insulin needs [3-5], the risks of hypoglycaemic reactions in obese patients on hypocaloric diets $[6,7]$ or to avoid large blood glucose swings in brittle diabetes $[8,10]$. Nevertheless the efficacy of biguanides in Type 1 diabetic patients remains controversial [11].

The artificial pancreas has provided a reliable and reproducible method for assessing insulin needs in Type 1 diabetes $[12,13]$. The validity of the method has been confirmed recently in studies using pectin [14], guar-gum [15] and mixed meals [16]. We have tested the efficacy of a normal therapeutic dose of metformin in diminishing insulin delivery by the artificial pancreas in Type 1 diabetic subjects after a mixed meal.

\section{Patients and Methods}

The eight subjects (age: $26 \pm 3$ years; weight: $60 \pm 3 \mathrm{~kg}$; height: $171 \pm$ $3 \mathrm{~cm}$; duration of diabetes: $8 \pm 2$ years; daily dose of SC insulin: $75 \pm$ $4 \mathrm{U} /$ day; mean $\pm \mathrm{SEM}$ ) were fully informed diabetic volunteers without ketosis, renal failure or acute illness, whose insulin dependence was assessed according to age of onset, history and the lack of significant post-glucagon C-peptide response. Each patient, serving as his own control, received on two different occasions in the same week a standardized test meal $(630 \mathrm{Kcal}$; carbohydrate $60 \mathrm{~g}$, fat $30 \mathrm{~g}$, protein $30 \mathrm{~g}$ ) eaten in $10 \mathrm{~min}$ between 12.00 and $12.30 \mathrm{~h}$. Each test meal was pre- ceded by $48 \mathrm{~h}$ treatment with metformin ( $850 \mathrm{mg}$, twice daily) or placebo (in a random double-blind order), the last tablet being taken at $08.00 \mathrm{~h}$ on the day of the experiment. To avoid any residual effect of SC insulin, injections were discontinued $24 \mathrm{~h}$ before the experiment and the patients were placed on continuous IV insulin infusion until connection to the artificial pancreas between 07.00 and $08.00 \mathrm{~h}$ on the day of the experiment. Blood glucose levels and insulin infusion rates were recorded every $2 \mathrm{~min}$ for $180 \mathrm{~min}$ after the beginning of the meal. The procedure received the approval of the Ethical Commitee of the Hospital.

\section{Statistical Analysis}

Insulin delivery by the artificial pancreas was tested using a sequential analysis one-sided test-open plan as described by Armitage [17]. With this method, as soon as the tested parameters reach predetermined boundaries with chosen statistical risks of error, the study may be considered conclusive and ended. In our study, the main parameter tested was the difference in post-prandial insulin delivery by the artificial pancreas with and without metformin. We chose to consider as significant a decrease of three units of insulin for a meal, with a $\alpha$ risk of 0.01 and $\beta$ risk of 0.10 . Blood glucose levels were compared using Student's t-test for paired data.

\section{Results}

\section{Insulin Delivery by Artificial Pancreas}

The results of the sequential analysis are shown in Figure 1. After patient 8 , it was possible to conclude that the assigned limit of $3 \mathrm{U}$ insulin per patient per meal had 


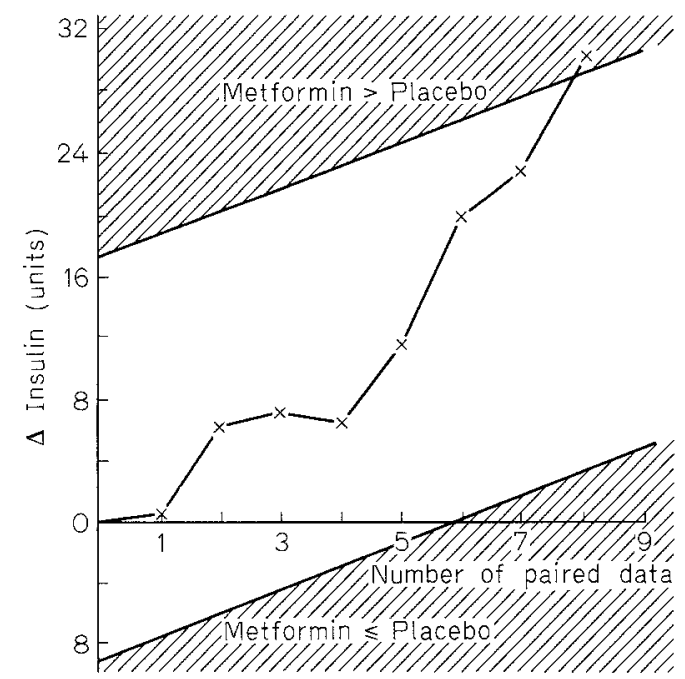

Fig. 1. Results of sequential analysis. $\triangle$ insulin $=[$ total insulin delivery during $180 \mathrm{~min}$ after meal with placebo] - [total insulin delivery after meal during same period with metformin]. Number of paired data $=$ number of patients receiving the two meals. Upper limit: Metformin superior to placebo; lower limit: Metformin inferior or equivalent to placebo

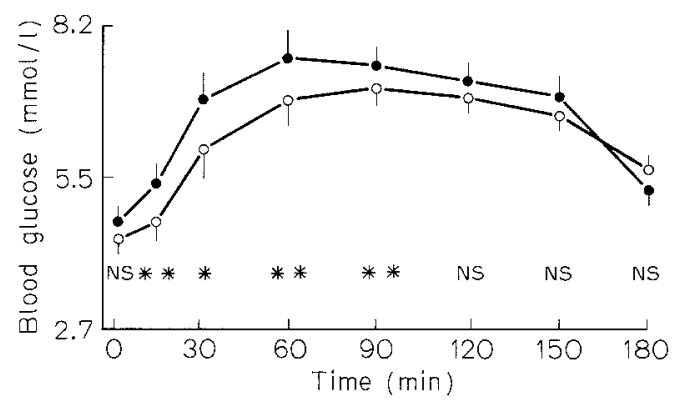

Fig. 2. Blood glucose changes during two test meals when preceded by placebo $(\longrightarrow)$ or metformin $(\mathrm{O}-\mathrm{O})$. Mean $\pm \mathrm{SEM}$ of eight observations. ${ }^{*} p<0.05,{ }^{* *} p<0.01$. NS: not significant

been reached, demonstrating a significant saving effect of metformin compared with placebo. The mean amount of insulin delivered by the artificial pancreas in $180 \mathrm{~min}$ was $19.2 \pm 3.5 \mathrm{U}$ with placebo and $15.3 \pm 2.0 \mathrm{U}$ with metformin $(p<0.01)$. The decrease in insulin delivery after metformin was $4.0 \pm 1.4 \mathrm{U}$ (mean \pm SEM), corresponding to a $26 \%$ reduction of the initial requirements.

\section{Blood glucose}

Figure 2 shows the mean blood glucose variations during 180 min following the two test meals. Blood glucose values were significantly lower in the metformin group at $15,30,60$ and $90 \mathrm{~min}$.

\section{Discussion}

The use of biguanides in Type 1 diabetes has been controversial. Some studies have shown that insulin requirements were significantly decreased during the adminis- tration of biguanides [3,11], an effect which seems to be maximal shortly after commencing the drug $[4,5]$. Some authors have also claimed that biguanides 'smooth out' blood glucose profiles in brittle diabetic patients [7, 10] but this has been denied by others $[3,5,11]$.

The artificial pancreas may be a good method for testing the efficacy of drugs or other treatments modifying blood glucose control in Type 1 diabetes, and perhaps easier than conventional clinical trials. In a previous study [16], we showed that the total amount of insulin delivered by artificial pancreas to restore basal blood glucose values after a meal was closely correlated with the total amount of carbohydrate in the meal, the results being reproducible in lean subjects. We have also used this method to assess the efficacy of pectin in Type 1 diabetes [14]. Similar results have been obtained for guar gum by other workers using an artificial pancreas [15].

This study therefore suggests that metformin is effective in reducing post-prandial blood glucose levels and insulin requirements in Type 1 diabetic subjects. The effect may be more pronounced in patients with high insulin requirements, but the number of such patients was too small to draw clear conclusions on this point. It should be noted, however, that the mean insulin delivery by the artificial pancreas after the test meal is higher in this small group of patients than in our previous work [16].

A decrease in insulin requirements may be of interest in diminishing peripheral hyperinsulinism and its possible consequences [18]. However, this study was not designed to show that the risk of insulin reaction was diminished or that metformin was effective in stabilizing brittle diabetes. It is indeed questionable whether the addition of metformin in the long term is to be recommended in Type 1 diabetic patients. Though the drug appears to be effective and generally well-tolerated, it has occasional troublesome side-effects and could potentially be dangerous in these patients who may develop renal and vascular complications of their diabetes [19].

Acknowledgements. We are indebted to Dr. M.Joffroy-Lavieuville for providing us with metformin and placebo. This study was supported by a grant of University Pierre et Marie Curie Paris VI and was presented at the Annual Meeting of the EASD, Amsterdam (16-19 September 1981).

\section{References}

1. Azerad E (1963) Le traitement du diabète de l'adulte par le N.N. dimethyl biguanide. Union Med Canada 92, 1251-1259

2. Metformin: current aspects and future developments (1979) Cudworth AG (ed) Proceedings of a Symposium held at the Lido de France, Jersey. Research and Clinical Forums, Tunbridge Wells, Kent, UK, pp 1-152

3. Ferguson AW, De la Harpe PD, Farquhar JW (1961) Dimethyl biguanide in the treatment of diabetic children. Lancet 2: 1367-1369

4. Lestradet H, Besse J, Billaud L (1960) Etude de l'action d'un biguanide (N.N.-diméthyl guanyl guanidine) sur un groupe de 235 enfants diabétiques. Presse Med 68:391-393 
5. Schatz H, Winkler G, Jonatha EM, Pfeiffer EF (1975) Studies on juvenile-type diabetes in children. Diab Metab 1:211-220

6. Leng-Levy J, Leng B, Aubertin J, Lacut JY, Le Gall F, Boget JC, Lenoir MP (1972) L'association biguanides-insuline dans le traitement de certains diabétiques. Bordeaux Med. 19:2659-2664

7. Oberdisse K, Jahnke K, Daweke H, Liebermeister H (1971) Pathophysiological aspects and clinical experience with biguanides in the treatment of diabetes and obesity in diabetes. In: Rodriguez RR, Vallence Owen J (eds) Proceedings of the VIIth Congress of the International Diabetes Federation, Buenos-Aires, 1970. Excerpta Medica, Amsterdam, pp 726-735

8. Bloom A, Kolbe RJ (1970) Phenformin in insulin-dependent diabetics. Br Med J 1: 660-662

9. Krall LP (1968) Ten years experience with biguanides in the treatment of diabetes mellitus. In: Oberdisse K, Daweke H, Michael G (eds) International Biguanide Symposium, Düsseldorf. Georg Thieme Verlag, Stuttgart, pp 161-166

10. Keen H, Jarrett RJ (1968) The use of biguanides in diabetes mellitus. Postgrad Med J 44: 466-471

11. Pirart J (1971) Failure of the biguanides to improve the control of unstable diabetes treated with insulin. Diabetologia 7:283-286

12. Lambert AE, Buysschaert M, Marchand E, Pierard M, Wojcik S, Lambotte L (1978) Determination of insulin requirements in brittle diabetic patients by the artificial pancreas. Diabetes 27:825-833

13. Mirouze J, Selam JL, Pham TC, Cavadore D (1977) Evaluation of exogenous insulin homeostasis by the artificial pancreas in insulindependent diabetes. Diabetologia 13:273-278

14. Poynard T, Slama G, Delage A, Tchobroutsky G (1980) Pectin effi- cacy in insulin treated diabetics assessed by the artificial pancreas. Lancet 1: 158

15. Christiansen JS, Bonnevie-Nielsen V, Svendsen PA, Rubin P, Rønn B, Nerup J (1980) Effect of guar gum on 24-hour insulin requirements of insulin-dependent diabetic subjects as assessed by an artificial pancreas. Diabetes Care 3: 659-662

16. Slama G, Klein JC, Delage A, Ardila E, Lemaignen H, Papoz L, Tchobroutsky $G$ (1981) Correlation between the nature and amount of carbohydrate in meal intake and insulin delivery by the artificial pancreas in 24 insulin-dependent diabetics. Diabetes 30: 101-105

17. Armitage P (1960) Sequential medical trials. Blackwell Scientific Publications, Oxford

18. Stout RW (1979) Diabetes and atherosclerosis. The role of insulin. Diabetologia 16:141-150

19. Gale EAM, Tattersall RB (1976) Can phenformin-induced lactic acidosis be prevented? $\mathrm{Br}$ Med $\mathrm{J} 2$ : $972-975$

Received: 18 August 1981

and in revised form: 1 April 1982

Dr. G. Slama

Service de Diabétologie

Hôtel Dieu

1 place du Parvis Notre-Dame

75181 Paris Cedex 04

France 